\title{
EFFECTS OF DAILY USED BAGS ON BIOMECHANICS CHARACTERISTIC OF ELEMENTARY STUDENTS
}

\section{INFLUENTA RUCSACURILOR UTILIZATE ZILNIC ASUPRA CARACTERISTICILOR BIOMECANICE ALE ELEVILOR DIN ÎNVĂTĂMÂNTUL PRIMAR}

\author{
Nan ZHOU ${ }^{1,2}$, Jing YAN ${ }^{2}$, Wuyong CHEN ${ }^{1 *}$, Caibo HU $^{3}$, Xiaoyan ZHANG ${ }^{2}$ \\ ${ }^{1}$ National Engineering Laboratory for Clean Technology of Leather Manufacture, Sichuan University, Chengdu 610065, China \\ ${ }^{2}$ Guangzhou Shiling Leather \& Leather Products Investigation Center Co. Ltd, Guangzhou, 510850, China \\ ${ }^{3}$ People's government of Shiling town, Huadu district, Guangzhou, 510850, China
}

\section{EFFECTS OF DAILY USED BAGS ON BIOMECHANICS CHARACTERISTIC OF ELEMENTARY STUDENTS}

\begin{abstract}
In order to evaluate the effects on biomechanics characteristic of daily used bags of elementary students, we select three different types of marketable school bags (backpack A with shoulder cushion design, backpack B with shoulder-back cushion design and Japanese backpack $\mathrm{C}$ with bio-mechanics optimization design). The mFLEX, Codamotion and Footscan were used to measure shoulder pressure, back pressure, body posture and plantar pressure on 8 elementary students (male and female ratio 3 to 5) with different loads equivalent to 5\%, $10 \%, 15 \%, 20 \%$ and $25 \%$ of their body weights. The results showed that the value of shoulder pressure, back pressure and trunk leaning angle change linearly with the load increasing, there is no significant impact of plantar pressure value. But, different bags significantly impacts on shoulder pressure and back pressure and body posture. Evaluation results showed that two optimization design bags ( $B$ and $C$ ) had no advantages on decreasing shoulder pressure, back pressure and trunk leaning angle.

KEY WORDS: loads, shoulder pressure, back pressure, body posture, plantar pressure, elementary students
\end{abstract}

INFLUENTA RUCSACURILOR UTILIZATE ZILNIC ASUPRA CARACTERISTICILOR BIOMECANICE ALE ELEVILOR DIN ÎNVĂTĂMÂNTUL PRIMAR

REZUMAT. Pentru a evalua influenţa rucsacurilor utilizate zilnic de elevii din învăţământul primar asupra caracteristicilor biomecanice, s-au selectat trei tipuri diferite de rucsacuri pentru scoală din comerţ (rucsacul A cu pernuțe în zona umerilor, rucsacul B cu pernuţe în zona umerilor şi a spatelui şi rucsacul japonez $\mathrm{C}$ cu design de optimizare a biomecanicii). S-au utilizat sistemele mFLEX, Codamotion şi Footscan pentru a măsura presiunea în zona umerilor, presiunea în zona spatelui, poziţia corpului şi presiunea plantară la 8 elevi din învăţământul primar (raportul dintre băieți şi fete a fost de 3 la 5), cu diferite sarcini echivalente cu 5\%, 10\%, 15\%, 20\% şi 25\% din greutăţile corporale ale acestora. Rezultatele au arătat că valorile presiunii în zona umerilor, ale presiunii în zona spatelui şi unghiul de înclinaţie al corpului se modifică liniar odată cu creşterea sarcinii, însă nu există niciun impact semnificativ al valorii presiunii plantare. Cu toate acestea, diferitele tipuri de rucsacuri au un impact semnificativ asupra presiunii în zona umerilor, în zona spatelui şi asupra posturii corpului. Rezultatele evaluării au arătat că cele două rucsacuri cu design de optimizare (B şi C) nu au avut niciun avantaj în privinţa scăderii presiunii în zona umerilor, în zona spatelui sau asupra unghiului de înclinație al corpului.

CUVINTE CHEIE: sarcini, presiunea în zona umerilor, presiunea în zona spatelui, postura corpului, presiune plantară, elevi primari

LES EFFETS DES SACS À DOS UTILISÉS QUOTIDIENNEMENT SUR LES CARACTÉRISTIQUES BIOMÉCANIQUES DES ÉLÈVES DE L'ENSEIGNEMENT PRIMAIRE

RÉSUMÉ. Afin d'évaluer les effets des sacs à dos utilisés quotidiennement sur les caractéristiques biomécaniques des élèves de l'enseignement primaire, on a sélectionné trois types de sacs à dos d'école commerciaux (sac à dos $\mathrm{A}$ avec des coussins dans la région les épaules, sac à dos $\mathrm{B}$ avec des coussins dans les région des épaules et du dos et le sac à dos japonais $\mathrm{C}$ avec l'optimisation biomécanique). Les systèmes MFLEX, Codamotion et Footscan ont été utilisés pour mesurer la pression dans les régions des épaules et du dos, la posture du corps et la pression plantaire chez 8 élèves de l'enseignement primaire (le rapport entre les garçons et les filles était 3-5) avec de différentes charges équivalant à $5 \%, 10 \%, 15 \%, 20 \%$ et $25 \%$ de leur poids corporel. Les résultats indiquent que la pression dans les régions des épaules et du dos et l'angle d'inclinaison des corps changent linéairement avec l'augmentation de la charge, mais il n'y a pas d'impact significatif de la valeur de la pression plantaire. Cependant, les différents types de sacs à dos ont un impact significatif sur la pression dans les régions des épaules et du dos et sur la posture du corps. Les résultats de l'évaluation ont montré que les deux sacs à dos avec optimisation (B et C) n'ont eu pas d'avantage sur la diminution de la pression dans les régions des épaules, du dos ou sur l'angle d'inclinaison du corps.

MOTS CLÉS : charges, pression sur les épaules, pression sur le dos, posture corporelle, pression plantaire, élèves de l'enseignement primaire

\section{INTRODUCTION}

As a convenient way of load carriage, a schoolbag is necessary for primary school students in the daily use. Reports showed that teenagers' shoulder and back pain, scoliosis and psychosis were closely related to the weight of schoolbag [1-5]. Currently, more and more scholars focus on the influence of different loading ways and weight on the human body, including changes of body posture and gait $[6,7]$. Reducing the bag weight was beneficial to reduce

\section{INTRODUCERE}

Rucsacul este utilizat zilnic de elevii din învățământul primar ca modalitate convenabilă de transportare a sarcinii. Rapoartele au arătat că durerile de umeri și de spate, scolioza și psihoza la adolescenți sunt strâns legate de greutatea rucsacului [1-5]. În prezent, din ce în ce mai mulți oameni de știință se concentrează asupra influenței diferitelor sarcini asupra corpului uman, inclusiv modificări ale posturii corpului și ale mersului [6, 7]. Reducerea greutății rucsacului duce la scăderea efectelor negative

\footnotetext{
* Correspondence to: Wuyong CHEN, National Engineering Laboratory for Clean Technology of Leather Manufacture, Sichuan University,
} Chengdu 610065, China, wuyong.chen@163.com 
the adverse effects on the human body, bag structure and the center of gravity optimization, and it also could reduce the possible damage to some extent $[8,9]$. Some studies have pointed out that bag's weight was not more than $10 \%$ of body weight [10-13], others said that $15 \%$ was the edge of security value [14]. At present, there is less research on the impacts of bio-mechanical effects on bags.

In the market, there are a great variety of schoolbags, mainly backpacks, trolley bags and shoulder bags. As the actual weight of schoolbag was overweight [8, 15], wearing single-shouldered and uneven loading bags might injure student body and lead to scoliosis [16]. Some studies indicated that symmetrical backpack should be chosen [17]. The trolley bag is a kind of "ease-burden" product, whose loadbearing mode was changed to avoid the physical injuries to the student, but the tray with wheels is weighty and not portable; therefore, the easy portable backpack is the most widely used now.

In this paper, the changes of shoulder pressure, back pressure, body posture and plantar pressure were studied in three different aspects-commercial backpacks with different weight. Besides, the harm of overweight and the influence of different structural bags were discussed to provide the scientific basis for the subsequent schoolbag design from the perspectives of bio-mechanics and physiology.

\section{METHODS}

\section{Participants}

Eight healthy students were selected from a local primary school to participate in this experiment. The students' conditions were stated as follows: palsy;

I. No foot operation history, no cerebral

II. Not suffering from scoliosis;

III. No foot injury;

IV. Able to walk independently, in normal gait.

The subjects' information is stated Table 1. asupra organismului uman, la optimizarea structurii rucsacului și a centrului de greutate, precum și la reducerea posibilelor daune într-o anumită măsură $[8,9]$. Unele studii au subliniat faptul că greutatea rucsacului nu a constituit mai mult de $10 \%$ din greutatea corporală [10-13], iar alții au fost de părere că $15 \%$ a reprezentat limita de siguranță [14]. În prezent, există foarte puține studii de cercetare cu privire la impactul efectelor biomecanice asupra rucsacurilor.

Există o mare varietate de genți pentru școală pe piață, în principal, rucsacuri, ghiozdane tip troler și genți de umăr. Întrucât greutatea reală a rucsacului este prea mare $[8,15]$, purtarea genților pe un singur umăr sau cu încărcare inegală ar putea dăuna organismului elevului, conducând la scolioză [16]. Unele studii au indicat faptul că rucsacul simetric este recomandat [17]. Trolerul este un produs care ușurează sarcina, al cărui mod de transportare a greutății a fost modificat pentru a evita leziunile fizice ale elevului, însă sistemul cu roți este greu și incomod, prin urmare, în prezent cel mai des utilizat este rucsacul purtat pe umeri.

În această lucrare s-au studiat modificările presiunii în zona umerilor și a spatelui, postura corpului și presiunea plantară utilizând trei rucsacuri comerciale cu aspect și greutate diferite. În plus, s-au discutat efectele negative ale excesului de greutate și influența diferitelor structuri ale rucsacurilor pentru a oferi o bază științifică pentru proiectarea ulterioară a ghiozdanelor din perspectiva biomecanicii și fiziologiei.

\section{METODE}

\section{Participanţi}

S-au selectat pentru participare în acest experiment opt elevi sănătoși dintr-o școală primară locală. Condițiile de selecție au fost următoarele:

I. să nu fi avut operații în zona piciorului, să nu sufere de paralizie cerebrală;

II. să nu sufere de scolioză;

III. să nu aibă leziuni la nivelul picioarelor; IV. să poată merge independent. Tabelul 1.

Table 1: Basic information of subjects

Tabelul 1: Informaţii de bază ale subiecţilor

\begin{tabular}{|c|c|c|c|c|c|c|c|c|}
\hline No. & 1 & 2 & 3 & 4 & 5 & 6 & 7 & 8 \\
\hline $\begin{array}{l}\text { Nr. crt. } \\
\text { Sex }\end{array}$ & $\begin{array}{l}\text { Female } \\
\text { Feminin }\end{array}$ & $\begin{array}{l}\text { Female } \\
\text { Feminin }\end{array}$ & $\begin{array}{c}\text { Male } \\
\text { Masculin }\end{array}$ & $\begin{array}{l}\text { Female } \\
\text { Feminin }\end{array}$ & $\begin{array}{c}\text { Male } \\
\text { Masculin }\end{array}$ & $\begin{array}{l}\text { Female } \\
\text { Feminin }\end{array}$ & $\begin{array}{l}\text { Female } \\
\text { Feminin }\end{array}$ & $\begin{array}{c}\text { Male } \\
\text { Masculin }\end{array}$ \\
\hline $\begin{array}{c}\text { Age/yr } \\
\text { Vârstă/ani }\end{array}$ & 9 & 6 & 8 & 11 & 9 & 8 & 7 & 10 \\
\hline $\begin{array}{l}\text { Height/cm } \\
\text { Înălţime/cm }\end{array}$ & 126 & 112 & 115 & 152 & 133 & 132 & 122 & 133 \\
\hline
\end{tabular}




\begin{tabular}{|c|c|c|c|c|c|c|c|c|}
\hline $\begin{array}{l}\text { Weight } / \mathrm{kg} \\
\text { Greutate/kg }\end{array}$ & 24.9 & 20 & 20.5 & 48.6 & 27.4 & 29.5 & 24.5 & 30.4 \\
\hline $\begin{array}{l}\mathrm{BMI} \\
\mathrm{IMC}\end{array}$ & 15.7 & 15.9 & 15.5 & 21.0 & 15.5 & 16.9 & 16.5 & 17.2 \\
\hline
\end{tabular}

Note: BMI, body mass index, or body weight index.

Of all the subjects, only No. 4 was overweight, the rest of the seven people kept their $\mathrm{BMI}$ in the normal range, and no one was underweight or fat.

Prior to the test, the staff communicated thoroughly with the guardians of subjects about the test flow and precautions, and written consents were obtained from them prior to data collection. All tests were approved by the local Ethics Committee, and were conducted according to the Declaration of Helsinki.

\section{Test Bags}

In the test, students wore three types of marketable school backpacks: backpack $A$ (see Figure 1a) with shoulder cushion design, backpack B (see Figure 1b) with shoulder-back cushion design and Japanese backpack $C$ (see Figure 1c) with bio-mechanics optimization design. Firstly, the load weight was determined by each subject's body weight. Load weights were $5 \%, 10 \%, 15 \%, 20 \%$ and $25 \%$ of body weight respectively. In the test, subjects wore the schoolbags, which is $5 \%$ of body weight, increasing the load weight in order to reach $25 \%$ of body weight.
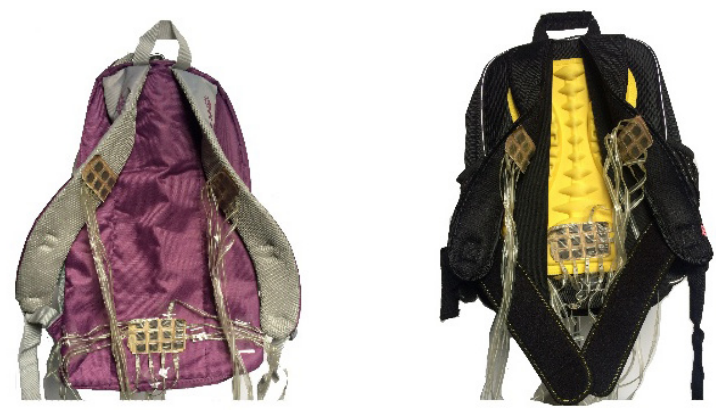

Obs.: IMC, indice de masă corporală

Dintre toți subiecții, doar subiectul nr. 4 a prezentat exces de greutate, celelalte șapte persoane au avut IMC în limite normale și nu au existat subiecți subponderali sau grași.

Înaintea testării, personalul a informat în detaliu părinții subiecților cu privire la procedura de testare și măsurile de precauție și s-au obținut acorduri scrise de la aceștia înainte de colectarea datelor. Toate testele au fost aprobate de către comitetul de etică local și s-au desfășurat în conformitate cu Declarația de la Helsinki.

\section{Rucsacurile testate}

În cadrul testului, elevii au purtat trei tipuri de rucsacuri comerciale: rucsacul A (a se vedea Figura 1a), cu pernuțe la nivelul umerilor, rucsacul B (a se vedea Figura 1b), cu pernuțe la nivelul umerilor și spatelui și rucsacul japonez $C$ (a se vedea Figura 1c) cu design de optimizare a biomecanicii. S-a determinat mai întâi greutatea sarcinii în funcție de greutatea corporală a fiecărui subiect. Greutățile sarcinilor au fost de $5 \%, 10 \%, 15 \%, 20 \%$, respectiv $25 \%$ din greutatea corporală. În cadrul experimentului, subiecții au purtat rucsacurile, care reprezentau $5 \%$ din greutatea corporală, mărind sarcina pentru a ajunge la $25 \%$ din greutatea corporală.
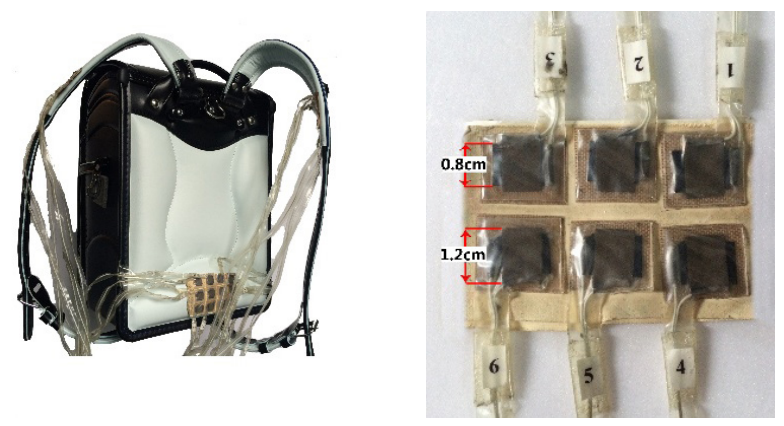

Figure 1. (a) Sensor position distribution backpack A, (b) Sensor position distribution backpack $B,(c)$ Sensor position distribution backpack C, (d) Sensor size

Figura 1. (a) Poziţia senzorului pe rucsacul $A$, (b) poziţia senzorului pe rucsacul $B$, (c) poziţia senzorului pe rucsacul $C,(d)$ dimensiunea senzorului

\section{Test Methods}

Prior to the test, subjects walked across the test area at a self-preferred speed in natural gait for a 2-3 minute warm-up practice trial wearing the backpack equipped with sensor. Data collection began after the student walking

\section{Metode de testare}

Înainte de experiment, subiectii s-au deplasat pe zona de testare, cu o viteză la alegere în mers natural timp de 2-3 minute, pentru încălzire, purtând rucsacul echipat cu senzor. Colectarea datelor a început în momentul în 
gait stability, and ended prior to stopping walking. Effective data of each load group needed to be collected 3 times.

The mFLEX pressure measuring system, which was researched in Rsscan international, Belgium, was utilized to gain the contact pressure between the body and the backpack. Prior to each test, strap length and sensor position were adjusted according to each primary school student's body condition. Installation method of mFLEX pressure sensor in the test was shown in Figure 1. In total, 24 pressure sensors were used from number 1-6 on the left shoulder, 7-12 on the right shoulder and 13-24 on the lower back. The area of pressure sensors is $0.96 \mathrm{~cm}^{2}$ and the frequency is $5 \mathrm{~Hz}$. Maximum pressure $(\mathrm{mmHg})$ in each area needed to be calculated.

Codamotion, a 3-D Motion Capture system (Charnwood Dynamics Ltd, England) was used to test forward lean angle of head and body, and the Odin software was used to collect data. The 3-D Motion Capture system included two motion captures, located in both sides of experiment aisle, could collect accurately the changes of mark points on the subjects walking in the aisle. The position of markers (diameter $=4 \mathrm{~mm}$ ) pasted in the joint point on the left side of the body were recorded to calculate corresponding angles, markers at tragus, acromion collar bone joints and femoral greater trochanter. Markers were the active infrared markers, driven by a driving box, each marked point was identified one by one by the system. The relative displacement of markers was ignored caused by the body movement.

Foot-scan plantar pressure measuring system (Rsscan, Belgium) was used to test plantar pressure, and plantar pressure measuring system (length $=1 \mathrm{~m}$ ) lay in the middle of aisle in a plane. The supporting software, Footscan7.0, was used to analyze data, the main analysis indicator was peak pressure of various plantar regions.

\section{Statistical Analysis}

All of the data were verified using 1-sample K-S test to check its normal distribution situation. All analytical models of the research were performed using SPSS (V20, SPSS Inc., Chicago, USA), significance was defined as 0.05 , confidence interval 95\%. care elevii au căpătat stabilitate în mers, și s-a încheiat înainte de oprirea mersului. A fost necesară colectarea de 3 ori a datelor efective ale fiecărei grupe de sarcină.

S-a utilizat sistemul de măsurare a presiunii mFLEX, produs de Rsscan International, Belgia, pentru a obține presiunea de contact dintre corp și rucsac. Înainte de fiecare test, s-au ajustat lungimea curelei și poziția senzorului în funcție de corpul fiecărui elev de școală primară. Metoda de instalare a senzorului de presiune mFLEX a fost prezentată în Figura 1. S-au utilizat în total 24 de senzori de presiune, de la 1 la 6 pe umărul stâng, de la 7 la 12 pe umărul drept și de la 13 la 24 pe partea inferioară a spatelui. Suprafața senzorilor de presiune este de 0,96 $\mathrm{cm}^{2}$, iar frecvența este de $5 \mathrm{~Hz}$. A fost necesar să se calculeze presiunea maximă $(\mathrm{mm} \mathrm{Hg})$ în fiecare regiune.

S-a utilizat sistemul de captare a mișcării 3D Codamotion (Charnwood Dynamics Ltd, Anglia) pentru a determina unghiul de înclinație al capului și al corpului, iar software-ul Odin a fost folosit pentru a colecta datele. Sistemul de captare a mișcării 3D a inclus două capturi de mișcare, din ambele părți ale culoarului de-a lungul căruia s-a desfășurat experimentul, colectând cu acuratețe modificările punctelor de reper la subiecții care s-au deplasat de-a lungul culoarului. S-a înregistrat poziția markerilor (diametru $=4 \mathrm{~mm}$ ) lipiți în zona articulațiilor de pe partea stângă a corpului (la nivelul tragusului, al articulației acromio-claviculare și al trohanterului mare) pentru a calcula unghiurile corespunzătoare. Markerii activi în domeniul infraroșu au fost dirijați cu ajutorul unui driver, fiecare punct marcat fiind identificat pe rând de către sistem. Deplasarea relativă a markerilor a fost ignorată, fiind cauzată de mișcarea corporală.

S-a utilizat sistemul Footscan de măsurare a presiunii plantare (Rsscan, Belgia) pentru a determina presiunea plantară, sistemul de măsurare (lungime $=1 \mathrm{~m}$ ) fiind poziționat în mijlocul culoarului. S-a utilizat programul Footscan 7.0 pentru a analiza datele, indicatorul de analiză principal fiind presiunea maximă în diferite regiuni plantare.

\section{Analiza statistică}

Toate datele au fost verificate folosind testul K-S cu un eșantion pentru a determina distribuția normală. Toate modelele analitice utilizate în studiu au fost efectuate cu ajutorul programului SPSS (V20, SPSS Inc., Chicago, SUA); nivelul de semnificație a fost definit la 0,05, iar intervalul de încredere a fost de 95\%. 

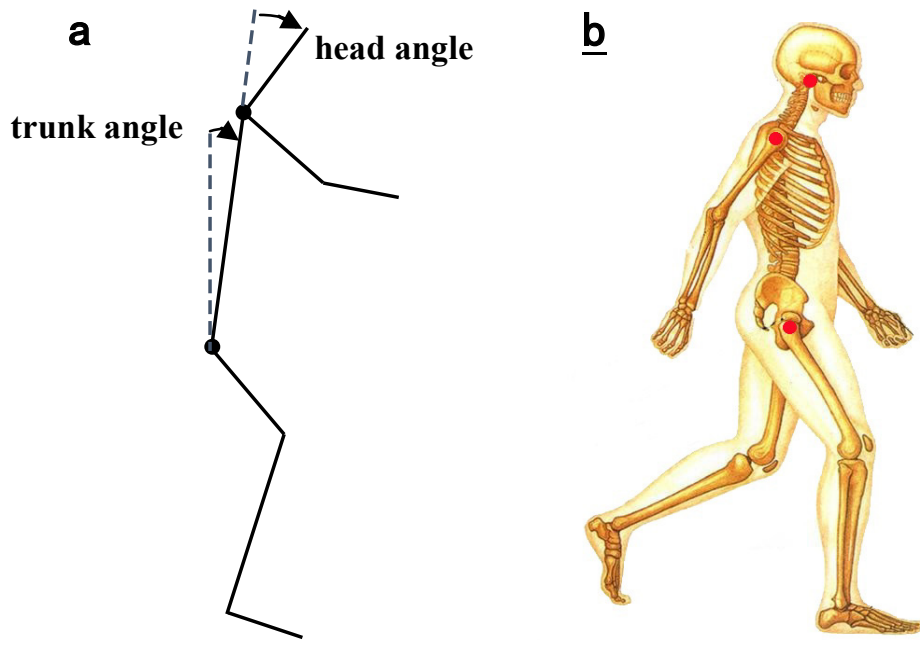

Figure 2. Definition of the forward-leaning angle (a), mark points position distribution (b)

Figura 2. Definirea unghiului de înclinaţie (a), distribuţia punctelor de presiune (b)
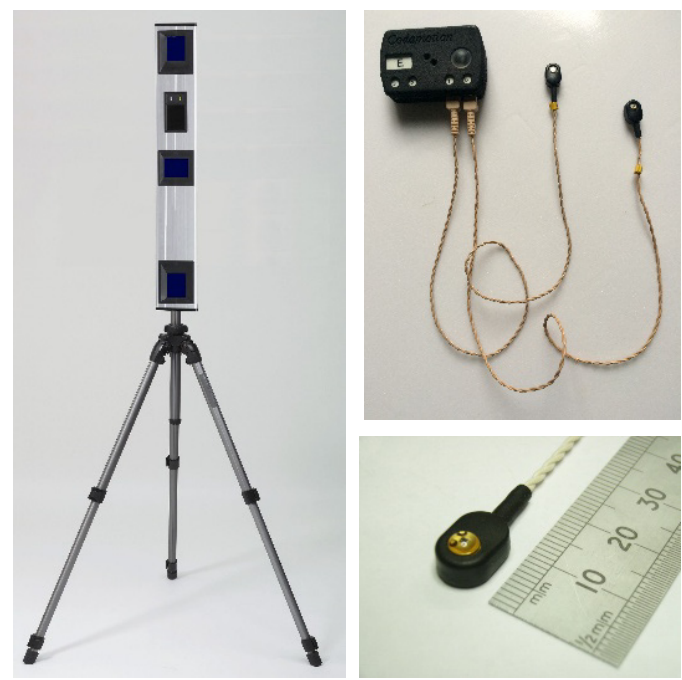

Figure 3. Codamotion 3-D motion capture system: (a) motion capture, (b) driver and (c) markers Figura 3. Sistemul de captare a mişcării 3D Codamotion: (a) captarea mişcării, (b) driver şi (c) markeri

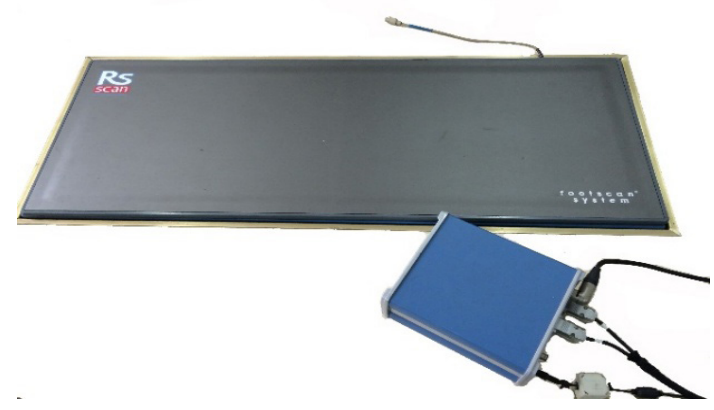

Figure 4. Footscan plantar pressure measuring system

Figura 4. Sistemul Footscan pentru măsurarea presiunii plantare 


\section{RESULT}

\section{The Influence of Bag Structure on the Shoulder Pressure and Back Pressure}

The maximum shoulder and back pressure values under different loading of eight subjects were recorded. The result was shown in Figure 5. With increased load weight, shoulders and back maximum pressure values of the three bags increased significantly. And all the maximum pressure values increased linearly along with the increase of load (left shoulder: $A R^{2}=0.9966$, $B R^{2}=0.9638, C R^{2}=0.9957$; right shoulder: $A$ $R^{2}=0.998, B R^{2}=0.9969, C R^{2}=0.9948$; back: $A$ $\left.R^{2}=0.9966, B R^{2}=0.9316, C R^{2}=0.9873\right)$. The result indicated that influence of load was obviously on back pressure condition.

\section{REZULTATE \\ Influenţa structurii rucsacului asupra presiunii în zona umerilor şi în zona spatelui}

S-au înregistrat valorile presiunii maxime pentru zona umărului și cea a spatelui la opt subiecți cu diferite sarcini. Rezultatul a fost prezentat în Figura 5. Pe măsură ce a crescut sarcina, valorile presiunii maxime în zona umărului și cea a spatelui la utilizarea celor trei rucsacuri a crescut în mod semnificativ. De asemenea, toate valorile presiunii maxime au crescut liniar odată cu creșterea sarcinii (umărul stâng: $A R^{2}=0,9966, B R^{2}=0,9638, C R^{2}=0,9957$; umărul drept: $A R^{2}=0,998, B R^{2}=0,9969, C R^{2}=$ 0,9948 ; spate: $A R^{2}=0,9966, B R^{2}=0,9316, C$ $\left.R^{2}=0,9873\right)$. Rezultatele au indicat că sarcina a influențat îndeosebi presiunea în zona spatelui.

Diferențele dintre rucsacurile cu structuri diferite au fost analizate utilizând testul One
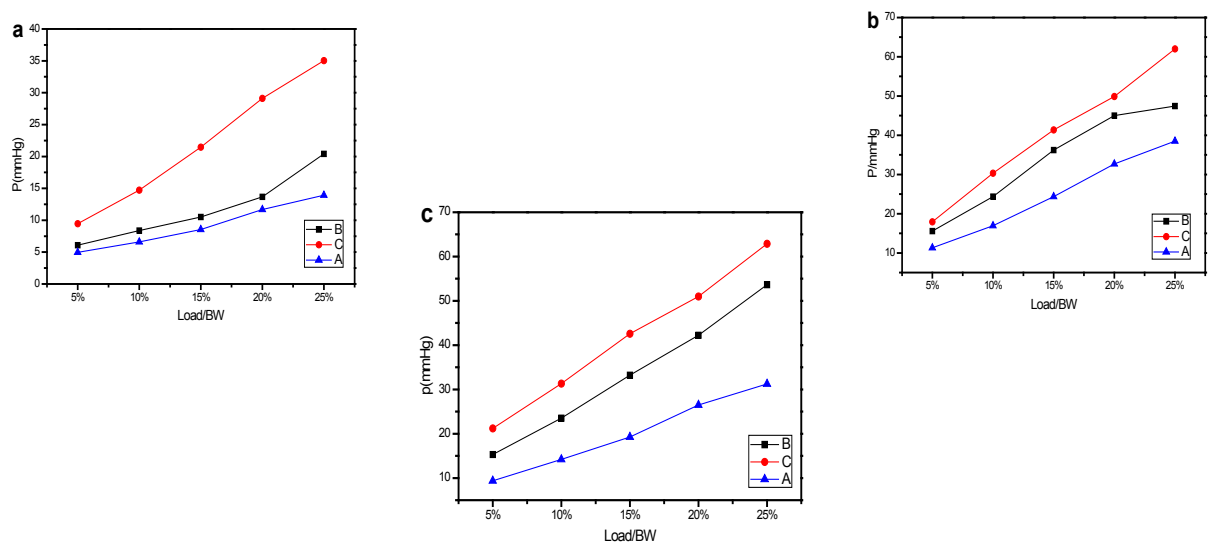

Figure 5. Mean maximum pressure value under various loading conditions of left shoulder (a), right shoulder (b) and back (c)

Figura 5. Valorile medii ale presiunii maxime în diferite condiţii de încărcare în zona umărului stâng (a), umărului drept (b) şi a spatelui (c)

The differences between different structure bags were analyzed by One Way ANOVA. Among them, the differences of shoulders pressure values between bag $A$ and the other two bags were striking (left shoulder: $\mathrm{P}_{A \& B}=0.020, \mathrm{P}_{A \& C}=0.000$; right shoulder: $P_{A \& B}=0.001, P_{A \& C}=0.000$ ), back pressure values of bag $C$ had significant differences as compared with that of bag $A$ and $B\left(P_{C \& A}=0.000, P_{C \& B}=0.000\right)$. The effect on the pressure value of the bags' structure was especially significant.

\section{Body Posture}

The Influence of Bag Structure on the

The mean values of forward lean angle of head and trunk in a gait cycle under different loading were showed in Figure 6. The trunk leaning angle increased linearly with the increasing of bag weight (Figure 6b). And the
Way ANOVA. Dintre acestea, diferențele valorilor presiunii la nivelul umerilor între rucsacul A și celelalte două rucsacuri au fost frapante (umărul stâng: $P_{A \& B}=0,020, P_{A \& C}=0,000$; umărul drept: $\left.P_{A \& B}=0,001, P_{A \& C}=0,000\right)$, valorile presiunii la utilizarea rucsacului $C$ au avut diferențe semnificative în comparație cu cele obținute în cazul rucsacurilor $\mathrm{A}$ și $\mathrm{B}\left(\mathrm{P}_{C \& A}=0,000, \mathrm{P}_{C \& B}=\right.$ 0,000 ). Influența structurii rucsacurilor asupra valorii presiunii a fost deosebit de semnificativă.

\section{Influenţa structurii rucsacului asupra posturii corpului}

Valorile medii ale unghiului de înclinație al capului și al corpului într-un ciclu de mers cu diferite sarcini au fost redate în Figura 6. Unghiul de înclinație al corpului crește liniar odată cu creșterea în greutate a rucsacului (Figura 6b). De asemenea, unghiul de înclinație al capului s-a modificat odată cu greutatea, dar tendința nu a fost evidentă.

Comparând influența diferitelor structuri ale rucsacurilor asupra poziției corpului, influența 
head angle also changed with the weight, but the trend was not obvious.

By comparing the influence of different structure bag on the body posture, the influence of bag $B$ and other two bags on values of forward lean angle of head and trunk was not significant, and difference between bag $A$ and $C$ was significant (forward lean angle of head: $P_{A \& C}=0.011$, trunk leaning angle: $P_{A \& C}=0.001$ ). Results show that bag structure had much effect on the body posture. rucsacului B și a celorlalte două rucsacuri asupra valorilor unghiului de înclinație al capului și al corpului nu a fost semnificativă, însă diferența dintre rucsacurile $\mathrm{A}$ și $\mathrm{C}$ a fost semnificativă (unghiul de înclinație al capului: $\mathrm{P}_{\mathrm{A \& C}}=0,011$, unghiul de înclinație al corpului: $\mathrm{P}_{\mathrm{A \& C}}^{\mathrm{A \& C}}=0,001$ ). Rezultatele arată că structura rucsacului a avut un efect semnificativ asupra posturii corpului.

Influenţa structurii rucsacului asupra presiunii plantare

Distribuția presiunii plantare a fost simetrică la purtarea rucsacurilor în timpul

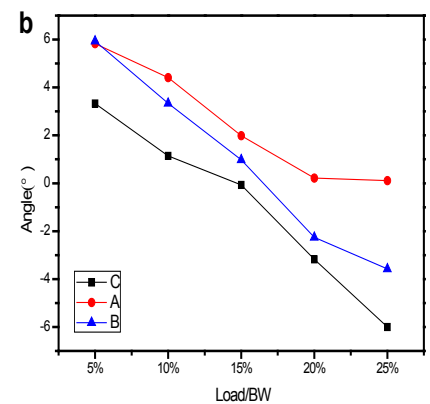

Figure 6. Changes of forward lean angle of head (a) and trunk (b)

Figura 6. Modificarea unghiului de înclinaţie al capului (a) şi al corpului (b)

\section{The Influence of Bag Structure on the Plantar Pressure}

For wearing backpack, plantar pressure distribution was symmetrical during walking. Therefore, plantar pressure distribution of left foot was chosen for example to analyze in this paper. As seen in Table 2, the plantar sub-regions dynamic peak pressure changed with the load; among them, the peak pressure of the medial area in forefoot (Meta2, Meta3, Meta4) and heel $(\mathrm{HM}, \mathrm{HL})$ increased by a great margin with bag $A$, but changed less with bag B or C. No significant changes were found in the effect of bag structure on plantar pressure during walking by comparing with the inter-group differences of the regional dynamic peak pressure among three bags.

The influence of load on the maximum peak in each region of plantar pressure was significant. When the load was less than 15\%, the maximum plantar peak pressure area of primary school students was heel (HM and $\mathrm{HL}$ ). When the load was increased to $15 \%$, peak pressure of Meta2, Meta3 and Meta4 were close to or more than that of HM and HL. The results showed that the peak pressure moved forward with load increasing during walking.

\section{DISCUSSION}

This research compared effects of three different structures of schoolbags to human mersului. Prin urmare, în această lucrare s-a selectat distribuția presiunii plantare a piciorului stâng pentru analiză. După cum arată Tabelul 2, presiunea maximă dinamică în regiunile plantare s-a modificat odată cu sarcina. Presiunea maximă în zona mediană a antepiciorului (metatarsienele 2, 3 și 4) și în zona călcâiului (regiunile externă și internă) a crescut cu o marjă mare în cazul rucsacului $A$, dar s-a modificat mai puțin în cazul rucsacurilor B și C. Nu s-au constatat modificări semnificative în influența structurii rucsacurilor asupra presiunii plantare în timpul mersului, prin compararea cu diferențele inter-grup ale presiunii maxime dinamice regionale la utilizarea celor trei rucsacuri.

Influența sarcinii asupra presiunii maxime în fiecare regiune plantară a fost semnificativă. Când sarcina a fost mai mică de $15 \%$, zona cu presiune plantară maximă în cazul elevilor din învățământul primar a fost cea a călcâiului (regiunile externă și internă). Când sarcina a crescut la 15\%, presiunea maximă în regiunea metatarsienelor 2, 3 și 4 a fost apropiată sau mai mare decât cea din regiunile externă și internă ale călcâiului. Rezultatele au arătat că presiunea maximă s-a deplasat înainte odată cu creșterea sarcinii în timpul mersului.

\section{DISCUTII}

Acest studiu a comparat efectele a trei rucsacuri cu structuri diferite asupra biomecanicii corpului uman, în principal, cu privire la trei aspecte: presiunea în zona umărului 
Table 2: Peak pressure value of each foot region under different types bags with different loading $\left(\mathrm{n}=8, \mathrm{~N} / \mathrm{cm}^{2} \bullet \mathrm{ms}\right)$

Tabelul 2: Valorile presiunii maxime în fiecare zonă a piciorului la utilizarea rucsacurilor de diferite tipuri şi sarcini $\left(\mathrm{n}=\mathbf{8}, \mathrm{N} / \mathrm{cm}^{2} \bullet \mathrm{ms}\right)$

\begin{tabular}{|c|c|c|c|c|c|c|c|c|c|c|c|c|c|c|c|c|}
\hline & $0 \%$ & $5 \%$ & $10 \%$ & $\begin{array}{l}\mathrm{A} \\
15 \%\end{array}$ & $20 \%$ & $25 \%$ & $5 \%$ & $10 \%$ & $\begin{array}{l}\mathrm{B} \\
15 \%\end{array}$ & $20 \%$ & $25 \%$ & $5 \%$ & $10 \%$ & $\begin{array}{l}\mathrm{C} \\
15 \%\end{array}$ & $20 \%$ & $25 \%$ \\
\hline $\begin{array}{l}\text { Meta } 1 \\
\text { Metatarsian } 1\end{array}$ & 1.493 & 1.252 & 1.305 & 1.686 & 2.005 & 1.529 & 0.579 & 0.846 & 0.875 & 0.713 & 1.467 & 1.033 & 1.200 & 1.667 & 0.911 & 0.944 \\
\hline $\begin{array}{l}\text { Meta } 2 \\
\text { Metatarsian } 2\end{array}$ & 2.420 & 2.443 & 2.100 & 3.876 & 3.371 & 3.733 & 1.538 & 1.392 & 1.863 & 1.583 & 2.446 & 2.539 & 2.450 & 3.094 & 2.583 & 2.806 \\
\hline $\begin{array}{l}\text { Meta } 3 \\
\text { Metatarsian } 3\end{array}$ & 3.777 & 3.052 & 3.000 & 3.876 & 6.105 & 4.276 & 2.654 & 1.629 & 2.008 & 2.183 & 3.429 & 4.367 & 3.394 & 3.839 & 5.111 & 3.950 \\
\hline $\begin{array}{l}\text { Meta } 4 \\
\text { Metatarsian } 4\end{array}$ & 3.107 & 2.043 & 2.367 & 3.162 & 5.286 & 4.405 & 2.967 & 1.175 & 2.100 & 2.733 & 2.254 & 3.033 & 3.628 & 2.839 & 4.456 & 3.294 \\
\hline $\begin{array}{l}\text { Meta } 5 \\
\text { Metatarsian } 5\end{array}$ & 1.393 & 0.524 & 0.819 & 0.967 & 2.219 & 0.862 & 1.188 & 0.308 & 0.875 & 0.983 & 0.637 & 1.311 & 1.311 & 1.033 & 1.344 & 1.106 \\
\hline $\begin{array}{l}\text { Midfoot } \\
\text { Zona centrală }\end{array}$ & 0.937 & 0.867 & 0.724 & 0.986 & 1.352 & 0.938 & 1.100 & 0.750 & 0.721 & 0.904 & 0.913 & 1.006 & 0.611 & 0.622 & 0.561 & 0.650 \\
\hline $\begin{array}{l}\text { Toe } 1 \\
\text { Degetul } 1\end{array}$ & 2.433 & 2.157 & 1.443 & 1.471 & 2.690 & 2.929 & 1.071 & 1.383 & 1.317 & 1.254 & 1.667 & 1.694 & 1.506 & 1.628 & 1.250 & 1.572 \\
\hline $\begin{array}{l}\text { Toe 2-5 } \\
\text { Degetele 2-5 }\end{array}$ & 0.957 & 0.824 & 0.348 & 0.395 & 1.157 & 0.695 & 0.283 & 0.275 & 0.313 & 0.550 & 0.567 & 0.428 & 0.339 & 0.472 & 0.383 & 0.344 \\
\hline $\begin{array}{l}\text { Heel Lateral } \\
\text { Călcâi extern }\end{array}$ & 2.707 & 2.519 & 2.486 & 3.805 & 4.710 & 3.990 & 3.071 & 2.225 & 2.200 & 2.675 & 3.075 & 2.294 & 2.328 & 2.233 & 2.444 & 2.878 \\
\hline $\begin{array}{l}\text { Heel Medial } \\
\text { Călcâi intern }\end{array}$ & 3.810 & 2.924 & 3.262 & 3.933 & 5.152 & 5.214 & 3.092 & 3.233 & 3.017 & 3.554 & 3.492 & 3.122 & 2.850 & 3.211 & 2.617 & 3.872 \\
\hline
\end{tabular}

body bio-mechanics, mainly from three aspects: shoulder-back pressure, body posture and plantar pressure. Results indicated that the pressure values of $A$ bag (only with shoulder cushion design) were significantly less than that of bag $B$ or C (with human bio-mechanics of optimization design), which turned our traditional view of the pressure and it also can relieve pressure by the bag with optimize structure. In respects of body posture, the change of the forward lean angle of head and trunk under different load conditions with bag $A$ was minimal. It might be because the back cushion of $B$ and $C$ bags was above a hard board, and the hard board shape is not easy to change. When the load increases, students changed the position of the center of gravity by trunk leaned to balance torque backwards, so the greater the counterpoise torque, the bigger the trunk leaning angle was. But schoolbag $A$ was made of polyester cloth and was easily changed. So wearing the bag $A$, the trunk leaning angle changed the least.

The forward lean angle of body increased with the increase in load, so the student may strain the neck muscle after long-term wearing overweight backpack, and the spine mechanics balance is destroyed, even cervical dislocation leads to abnormal curved spine. Pressure peak și a spatelui, postura corpului și presiunea plantară. Rezultatele au indicat faptul că valorile presiunii în cazul rucsacului $A$ (cu pernute în zona umărului) au fost semnificativ mai mici decât în cazul rucsacurilor B și C (cu design de optimizare a biomecanicii), ceea ce a schimbat viziunea noastră tradițională privind presiunea, aceasta putând fi ameliorată și prin utilizarea rucsacurilor cu structură optimizată. în ceea ce privește postura corpului, modificarea unghiului de înclinație al capului și al corpului în diferite condiții de încărcare în cazul rucsacului $A$ fost minimă. Aceasta s-ar putea datora faptului că pernuța de pe spatele rucsacurilor $\mathrm{B}$ și $\mathrm{C}$ a fost poziționată peste o placă dură, a cărei formă nu se poate schimba cu ușurință. La creșterea sarcinii, elevii au schimbat poziția centrului de greutate prin aplecarea în față a trunchiului pentru a echilibra efortul de torsiune, așadar, cu cât este mai mare cuplul contragreutate, cu atât este mai mare unghiul de înclinație al corpului. Însă rucsacul A confecționat din pânză de poliester s-a modificat cu ușurință. Astfel, la purtarea rucsacului $A$, unghiul de înclinație al corpului s-a modificat cel mai puțin.

Unghiul de înclinație al corpului a crescut odată cu creșterea sarcinii, astfel încât elevul își poate suprasolicita mușchiul gâtului după purtarea rucsacului cu exces de greutate pe termen lung, iar echilibrul mecanicii coloanei vertebrale este distrus, chiar și dislocarea la nivel cervical duce la curbarea anormală a coloanei vertebrale. Valoarea presiunii maxime este un 
value is an important index of reflecting the plantar pressure distribution [18], its size and the location have the important influence for the foot fatigue accumulation and injury happening [19]. The much high plantar pressure hurt the plantar foot easily, and made the area tissue damage. If the load is too heavy for a long time, it may affect the normal development of arch and development into flat feet. The foot area with too heavy pressure will form callous [20]. And callus, in turn, further increases the plantar pressure. In this study, when bag $A$ and bag $C$ weighed more than $15 \%$, and schoolbag B weighed more than $20 \%$, maximum plantar pressure forward when walking. It might be because the trunk leaning angle of student increased with load increasing, leading to the center of gravity moving forward. As the pupil arch muscle has not been fully developed, too much pressure will damage their feet. Therefore, it is suggested that schoolbag weight should not be more than $15 \%$ of the body weight.

The domestic and overseas experts studied the influence of the backpack on back pressure, body posture and plantar pressure of youth humeral, with different load, and very good research has been acquired. But there is little research about the influence of different backpack structure on the three aspects. Among them, Pascoe [8] studied the changes in body posture for 10 teenagers with four kinds of bags: with no bag, single shoulder schoolbag, backpack or single shoulder sports bags. The results indicated that the supporting abilities have enhanced observably; when we choose single shoulder bag, the rachis would side turn; when we choose two shoulder bag, the trunk angle was bigger. Backpack was chosen in this study, the trunk leaning angle increased significantly with the load, this was consistent with conclusion of others.

\section{CONCLUSIONS}

These results indicated that when carrying the bag $A$, variation of shoulder-back pressure and trunk leaning angle were minimum. The two optimization design bags $B$ and $C$ did not have an advantage on alleviating shoulder-back pressure and decreasing trunk leaning angle. Therefore, ordinary bag A may be more suitable for primary school students. indicator important care reflectă distribuția presiunii plantare [18], intensitatea și poziția acesteia influențează în mod semnificativ acumularea oboselii la nivelul piciorului și riscul de apariție a leziunilor [19]. O presiune plantară foarte mare poate cu ușurință provoca leziuni la nivelul piciorului și deteriora țesutul. Dacă se menține o sarcină prea mare pentru o perioadă lungă de timp, aceasta poate afecta dezvoltarea normală a bolții și apariția piciorului plat. La o presiune prea mare se vor forma calozități în zona picioarelor [20], iar acestea, la rândul lor, vor crește și mai mult presiunea plantară. În acest studiu, atunci când rucsacul A și rucsacul C au cântărit mai mult de $15 \%$, iar rucsacul B mai mult de $20 \%$, presiunea plantară maximă s-a deplasat înainte în timpul mersului. Aceasta se poate datora creșterii unghiului de înclinație al corpului odată cu creșterea sarcinii, ceea ce duce la deplasarea centrului de greutate înainte. Din cauza nedezvoltării mușchiului bolții la elevi, o presiune prea mare poate provoca leziuni la nivelul picioarelor. Prin urmare, se sugerează că greutatea rucsacului nu trebuie să depășească $15 \%$ din greutatea corporală.

Experții naționali și din străinătate au studiat influența rucsacului asupra presiunii la nivelul spatelui, posturii corpului și presiunii plantare la nivelul humerusului la subiecți tineri, cu sarcini diferite, obținând informații foarte bune, însă cercetările influenței diferitelor structuri ale rucsacurilor asupra celor trei aspecte au fost puține. Printre aceștia, Pascoe și colab. [8] au studiat modificările posturii corpului la 10 adolescenți în patru situații: fără rucsac, cu rucsac purtat pe un singur umăr, cu rucsac purtat pe ambii umeri sau cu geantă sport purtată pe un singur umăr. Rezultatele au indicat faptul că abilitățile de susținere au sporit perceptibil; atunci când alegem rucsacul purtat pe un singur umăr, coloana vertebrală se deplasează lateral; atunci când alegem rucsacul purtat pe ambii umeri, unghiul de înclinație al corpului a crescut. În acest studiu s-a ales rucsacul, iar unghiul de înclinație al corpului a crescut în mod semnificativ odată cu creșterea sarcinii, rezultate în concordanță cu concluzia altor cercetători.

\section{CONCLUZII}

Aceste rezultate au indicat faptul că, la transportarea rucsacului $A$, variația presiunii la nivelul umerilor și al spatelui și unghiul de înclinație al corpului au fost minime. Cele două rucsacuri cu design de optimizare $B$ și $C$ nu au avut niciun avantaj în privința micșorării presiunii în zona umeri-spate și a unghiului de înclinație al corpului. Prin urmare, rucsacul obișnuit A pare a fi mai potrivit pentru elevii de școală primară. 


\section{Acknowledgments}

The author would like to thank those who provided financial support, Science Plan Project (2012, HD12CXYG0016) of Huadu Area, Guangzhou, Guangdong.
Mulțumiri

Autorii doresc că mulțumească pentru sprijin financiar programului Science Plan Project (2012, HD12CXYG0016) din regiunea Huadu, Guangzhou, Guangdong.

\section{REFERENCES}

1. Birrell, S.A., Haslam, R.A., Subjective skeletal discomfort measured using a comfort questionnaire following a load carriage exercise, Mil Med, 2009, 174, 2, 177-182.

2. Mehta, T.B., Thorpe, D.E., Freburger, J.K., Development of a survey to assess backpack use and neck and back pain in seventh and eighth graders, Pediatr Phys Ther, 2002, 14, 4, 171-184.

3. Navuluri, N., Navuluri, R.B., Study on the relationship between backpack use and back and neck pain among adolescents, Nurs Health Sci, 2006, 8, 4, 208-215.

4. Korovessis, P., Koureas, G., Zacharatos, S. et al., Backpacks, back pain, sagittal spinal curves and trunk alignment in adolescents: A logistic and multinomial logistic analysis, Spine, 2005, 30, 2, 247-255.

5. Zhou, N., Chen, W., Yang, L., Zhou, J., Application and Perspective of Biomechanics Analytic Technology in Design of Bags, Leather Science and Engineering, 2015, 25, 5, 27-32.

6. Wang, M., Lu, A., Zhang, Q. et al., Research on the Influence of Backpack on the Balance, Posture and Gait of the Youngsters, Sports Scientific Research, 2015, 36, 2, 8-12.

7. Frank, E., Stevenson, J.M., Stothart, P., The effect of load placement on static posture and reaction forces in youth, Med Sci Sport Exercise, 2003, 35, 5, S21.

8. Pascoe, D.D., Pascoe, D.E., Wang, Y.T. et al., Influence of carrying book bags on gait cycle and posture of youths, Ergonomics, 1997, 40, 6, 631-640.

9. Chansirinukor, W., Wilson, D., Dansie, B., Effects of backpacks on students: Measurement of cervical and shoulder posture, Aust J Physiother, 2001, 47, 2, 110-120.

10. Hong, Y., Brueggemann, G.P., Changes in gait patterns in 10-year-old boys with increasing loads when walking on a treadmill, Gait Posture, 2000, 11, 3, 254-259.

11. Li, J.X., Hong, Y.L., Robinson, D.P., The effect of load carriage on movement kinematics and respiratory parameters in children during walking, Eur J Appl Physiol, 2003, 90, 1-2, 35-43.

12. Zhou, N., Zhou, J., Yang, L. et al., Investigation of the Effect of Varied Schoolbag Weight on the Health of Primary Students: A Quantitative Plantar Pressure Study, Revista de Pielarie Incaltaminte (Leather and Footwear Journal), 2015, 15, 3, 159-168.

13. Zhou, N., Yan, J., Zhou, J. et al., Effects of different loads schoolbags on body posture of elementary students, China Leather, 2016, 45, 2, 69-73.

14. Hong, Y., Cheung, C.K., Gait and posture responses to backpack load during level walking in children, Gait Posture, 2003, 17, 1, 28-33.

15. Zhu, H., Ma, J., Liu, E.Q. et al., Investigation on school bag-related hygienic problems among primary and secondary school students in Beijing, Chinese Journal of School Health, 2001, 22, 1, 26-27.

16. Geng, H., Foot pressure features of single-shoulder and double-shoulder schoolbag weight walk of children, Journal of Clinical Rehabilitative Tissue Engineering Research, 2011, 15, 33, 6267-6270.

17. Negrini, S., Negrini, A., Postural effects of symmetrical and asymmetrical loads on the spines of schoolchildren, Scoliosis, 2007, 2, 8, 1-7.

18. Chen, Z., Zhang, Y., Zhen, Z. et al., Quantitative Evaluation of Postoperative EFFECT of Calcaneal Fractures Using, Chinese Journal of Reparative and Reconstructive Surgery, 2009, 23, 8, 925-929.

19. Cheng, L., The analysis on distribution characteristics of thenar pressure parameter of the elderly people who have fell down, Changchun: Northeast Normal University, 2010.

20. Meng, Z., Yuan, W., Distribution of Planter Pressure in School Children during Walking with Different Loads on Their Backs, Journal of Biomedical Engineering, 2008, 5, 4, 852-855.

Article received/Data primirii articolului: 28.06.2016

Accepted/Acceptat la data: 12.09.2016 